\title{
Wyrok Sądu Metropolitalnego w Katowicach (c. Sobański) z 21.12.2007 r. z tytułu niezdolności pozwanej do podjęcia istotnych obowiązków małżeńskich
}

Ius Matrimoniale 13 (19), 209-213

2008

Artykuł został opracowany do udostępnienia w internecie przez Muzeum Historii Polski w ramach prac podejmowanych na rzecz zapewnienia otwartego, powszechnego i trwałego dostępu do polskiego dorobku naukowego i kulturalnego. Artykuł jest umieszczony w kolekcji cyfrowej bazhum.muzhp.pl, gromadzącej zawartość polskich czasopism humanistycznych i społecznych.

Tekst jest udostępniony do wykorzystania w ramach dozwolonego użytku. 


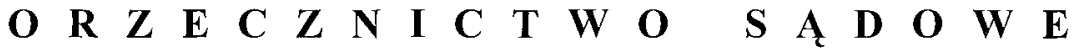

Ius Matrimoniale 13 (19) 2008

\section{Wyrok Sądu Metropolitalnego w Katowicach (c. Sobański) z 21. 12. $2007 \mathrm{z}$ tytułu niezdolności pozwanej oraz/lub powoda do podjęcia istotnych obowiązków małżeńskich}

\section{Przebieg sprawy}

AL oraz MO zawarli małżeństwo 26. 4. 1980 w kościele (...). Ważność tego małżeństwa zaskarżył AL 24. 10. 2002 w Sądzie Biskupim w (...), ,Z powodu niepodjęcia współżycia cielesnego przez pozwana". Skargę przyjęto 5. 11. 2002, a przedmiot sporu ustalono - po wystuchaniu stron - 7. 7. 2007 następującą formułą: „Czy małżeństwo stron jest nieważne $\mathrm{z}$ tytułu: 1) niezdolności dokonania stosunku małżeńskiego uprzednia i trwała po obu stronach (kan. 1084 $\S 1$ oraz 2) niezdolność do podjęcia istotnych obowiązków małżeńskich z przyczyn natury psychicznej po obu stronach (kan. $10953^{\circ}$ ) lub 3) okoliczności niedopełnienia małżeństwa". Sprawę zakończono 14. 12. 2004 wyrokiem stwierdzającym, że ,nieważność tego małżeństwa nie została udowodniona $\mathrm{z}$ żadnego $\mathrm{z}$ rozpatrywanych tytułów". Zdaniem Trybunału nie została też rozstrzygnięta watpliwość co do konsumacji tego małżeństwa. Wskutek apelacji powoda sprawa znalazła się w Trybunale II instancji. Trybunał postanowił 6. 6. 2005 przyjać apelację i prowadzić sprawę z tytułów rozpatrywanych poprzednio w I instancji. Sędziowie Trybunału apelacyjnego na sesji 19. 6. 2006 zatwierdzili wyrok I instancji odnośnie do impotencji (obydwu stron), stwierdzili natomiast, że została udowodniona nieważność małżeństwa $z$ tytułu niezdolności powoda i pozwanej do podjęcia istotnych obowiazków małżeńskich. Tym samym uchylili - odnośnie do niezdolności psychicznej stron - wyrok Trybunału I instancji. Na prośbę powoda Najwyższy Trybunał Sygnatury Apostolskiej reskryptem z 27. 8. 2007 (Prot. N. 39599/07 CP) wyznaczył Sąd Metropolitalny w Katowicach do rozpatrzenia sprawy w III instancji. Trybunał kolejny ukonstytuował się 4. 10. 2007. Akta sprawy nadeszły 9.10. 2007. Strony nie przedłożyły wniosków dowodowych, powód wnosi o zatwierdzenie wyroku II instancji, pozwana o jego uchylenie. 


\section{Prawny i faktyczny stan sprawy}

1. Na materiał dowodowy w rozpatrywanej sprawie, nagromadzony w poprzednich instancjach składają się zeznania stron (dwukrotne), zeznania dwóch świadków, świadectwo dziewictwa pozwanej, opinia biegłego psychiatry-seksuologa oraz biegłego psychologa.

2. Powód uważa, że pozwana nie była zdolna do małżeństwa, ponieważ nie chciała z nim współżyć. Jest to jedyny argument wysuwany przez powoda na poparcie tezy procesowej, powód przyznaje, „byliśmy dojrzali, odpowiedzialni i zdolni do zawarcia małżeństwa". Pozwana nie przytacza żadnych argumentów na niezdolność swoją czy powoda, lecz uważa, że obydwie strony zgodnie wypełniały obowiązki małżeńskie. W szczególności uważa siebie za zdolną do współżycia, do którego jednak powód nie potrafił jej ,przygotować przez okazanie czułości".

3. Świadkowie (matka i siostra powoda) nie wnoszą niczego do sprawy. Zdaniem świadków ,strony prowadzily w sposób normalny gospodarstwo domowe, życie stron układało się harmonijnie" (siostra powoda). Zmiany nastapiły w 20 lat po ślubie, matka powoda podejrzewa, że wskutek kontaktów powoda „z pewną kobietą". Wtedy powód zwierzył się siostrze, że ,małżeństwo nie zostało nigdy skonsumowane".

4. Biegły psychiatra-psycholog opiniujący w I instancji przytacza wypowiedź powoda, że ten ,uważa się za normalnego i zdrowego mężczyznę zarówno pod względem fizycznym, umysłowym, psychicznym i seksuologicznym". Wedle biegłego (który badał jedynie powoda) trudności we współżyciu były najprawdopodobniej spowodowane „brakiem przygotowania obydwojga do życia seksualnego, małymi potrzebami seksualnymi partnerów, powstaniem u nich nerwicowych zaburzeń seksualnych, w tym oziębłości względnej”. Biegły zdiagnozował też „niemoc płciową o charakterze względnym”, która powstała „wskutek traumatyzującej sytuacji we współżyciu małżeńskim". Co do osobowości powoda biegły nie stwierdził żadnych cech patologii.

5. Do badania u psychologa powołanego w II instancji przybyły obydwie strony. Odnośnie do powoda biegły twierdzi: „nie posiadal dojrzałości psychologicznej do zawarcia małżeństwa, a w szczególności dojrzałości socjalnej”. Na uzasadnienie tej opinii biegły podaje, że powód ,podczas zawierania małżeństwa był w trakcie kontynuowania studiów wyższych oraz nie posiadal stałej pracy zarobkowej, 
musiał więc być na utrzymaniu osób najbliższych". Kolejny argument to brak odpowiedzialności charakteryzujący powoda, ale nie widać, na czym biegły oparł to twierdzenie. Wreszcie - i to kolejny ,argument” - „przyczyną zawarcia małżeństwa nie było uczucie miłości”, a przyczyn tych dopatruje się biegły w nacisku pozwanej i - zarazem! - pragnieniu powoda opuszczenia domu rodzinnego. Biegły wyraźnie przyznaje, że testy nie wykazują u powoda zaburzeń psychotycznych ani osobowościowych, a jednak diagnozuje ,,swoiste zaburzenia osobowości w postaci osobowości lękliwej". Biegły wymienia szereg cech charakteryzujących taką osobowość (powściagliwość wobec intymnych relacji, obawa zawstydzenia czy ośmieszenia, niechęć do podejmowania ryzyka...). Sąd nie dostrzega, jakim wnioskowaniem biegły doszedł z tych przesłanek do wniosku o niezdolności powoda do podjęcia i wypełnienia istotnych obowiązków małżeńskich. Te cechy mogły utrudniać kontakty małżeńskie, nie uzasadniają wniosku o niezdolności chociażby dlatego, że te same cechy nie przeszkadzaja powodowi funkcjonować w innym związku (Biegły dopatruje się „okazywania niechęci do podejmowania osobistego ryzyka lub angażowania w nowe rodzaje aktywności", a to przecież powód nawiazał kontakt $\mathrm{z}$ inną kobietą i odszedł od pozwanej, mimo że ta chciała zatrzymać go przy sobie, i wniósł o rozwód). Najbardziej korzystna dla tezy powoda interpretacja mogłaby prowadzić najwyżej do wniosku o niezdolności psychicznej relatywnej, a ta nie powoduje nieważności małżeństwa. Nawet jednak w toku argumentacyjnym biegłego zdumiewa zdanie: „Bez watpienia nie był zdolny dochować dozgonności małżonce oraz trwać w zwiazku małżeńskim aż do śmierci". Ani z akt sprawy ani z referowanych przez biegłego badań testowych ani też z jego charakterystyki „osobowości lękliwej” nie wynika, by powód nie był w stanie trwać w nierozerwalnym związku małżeńskim. To, że powód ,wystapił z inicjatywą rozwodową" i ,przyczynił się do formalnego rozpadu" małżeństwa, nie uzasadnia twierdzenia, by był niezdolny do życia w dozgonnym związku.

6. Również odnośnie do pozwanej twierdzi biegły, że ,nie posiadała dojrzałości psychologicznej do zawarcia małżeństwa, a w szczególności dojrzałości społecznej". Argumenty biegły wysuwa dwa. Pierwszy to zeznanie powoda „uważam, że pozwana nie była zdolna do małżeństwa, ponieważ nie chciała współżyć ze mną". To, co powód „uważa”, jest dla biegłego argumentem! Drugi argument to wynik testu: „Wyniki testu DKO-74/k najwyraźniej wskazują 
u badanej na mieszane zaburzenie osobowości, na którą składają się elementy osobowości zależnej i obsesyjno-kompulsywnej". Następnie biegły wylicza cechy takiej osobowości i znajduje odpowiadające jej zachowania u pozwanej. Wśród nich: obawa przed rozwodem ,z powodu prawdopodobnego obniżenia się poziomu życia", postanowienie doprowadzenia do pojednania, dążenie do perfekcji i drobiazgowości w kwestii utrzymania czystości w mieszkaniu, „nadmierna sztywność w sprawach etyki i moralności" .... Ponadto twierdzi biegły, że pozwana „nie była w stanie spełniać aktów małżeńskich skierowanych ku prokreacji". Biegły przypisujacc wyłącznie pozwanej przyczyny nieudanego współżycia płciowego stron zupełnie pominał - odnotowane przecież przezeń - zeznania pozwanej w tej kwestii. Trzeba tu zauważyć, że w wyroku Trybunału II instancji wskazuje się na niemoc płciową względną powoda jako na przyczynę trudności w pożyciu płciowym stron. Trudno uznać, by opinia biegłego odnośnie do pozwanej opierała się na udowodnionych przesłankach.

7. W uzasadnieniu orzeczenia nieważności małżeństwa $\mathrm{w}$ wyroku Trybunału II instancji opinia biegłego to jedyny merytoryczny argument. Zdaniem Sądu nie znajduje on jednak oparcia w aktach. Sąd nie może bezkrytycznie przyjać ustaleń biegłego, gdyż musi „kierować się jednoznaczną zasada, że tylko niezdolność, a nie trudność w zakresie zgody małżeńskiej i urzeczywistniania prawdziwej wspólnoty życia i miłości, powoduje nieważność małżeństwa" (Jan Paweł II, Przem. z 5. 2. 1987 - L'Osserv. Rom. nr 2/1987, s. 32). „Hipotezę o istnieniu rzeczywistej niezdolności można wysunać jedynie w przypadku obecności poważnej anomalii" (Jan Paweł II, tamże), a takiej anomalii nie wykazano ani w odniesieniu do pozwanej ani w odniesieniu do powoda.

8. W aktach sprawy II instancji znajduje się dowód o dużym znaczeniu, mianowicie zaświadczenie lekarskie przysłane przez pozwana 9. 11. 2005. W zaświadczeniu tym, wydanym 28. 10. 2005 przez specjalistę położnictwa i chorób kobiecych, podano, że „,badaniem ginekologicznym z dnia 30. 4. 2004 stwierdzono zachowaną błonę dziewiczą u wyżej wymienionej pacjentki", czyli u pozwanej. Badanie przeprowadzono w 24 lata po zawarciu małżeństwa, które - jak wynikałoby z zaświadczenia - pozostało niedopełnione mimo prawie 22-letniego zgodnego pożycia stron (por. zeznania stron). Każda ze stron przypisuje drugiej przyczyny niedopełnienia małżeństwa. Faktycznych przyczyn nie zdołano ustalić. Sąd nie znajduje dowodów 

pozwanej oraz/lub powoda do podjęcia istotnych obowiązków małżeńskich

na to, by przyczyny te tkwily w sferze psychicznej którejś ze stron.

Wobec takiego stanu sprawy Sąd odpowiada przecząco na pytanie procesowe i stwierdza, że nie udowodniono niezdolności ani pozwanej ani powoda do podjęcia istotnych obowiązków małżeńskich. Tak więc Sąd orzeka, że nie udowodniono nieważności małżeństwa. Tym samym Sąd uchyla wyrok Trybunału II instancji w części orzekającej nieważność małżeństwa. 